\title{
ZASTOSOWANIE STATYSTYKI WIELOWYMIAROWEJ DO BADANIA KRYZYSU SUBPRIME
}

\begin{abstract}
Streszczenie
W artykule zastosowano metody analizy skupień z zakresu statystyki wielowymiarowej do badania okresu kryzysu finansowego. Zgodnie z tymi algorytmami zgrupowano indeksy giełdowe oraz kursy walutowe z okresów charakteryzujących się ich podwyższoną korelacją i szczególną zmiennościa. Przeprowadzono dyskusję nad możliwością zastosowania tej metody do generowania ram czasowych różnych okresów giełdowych. Analiza skupień umożliwiła poczynienie nowych obserwacji na temat kryzysu subprime.
\end{abstract}

Słowa kluczowe: analiza skupień, kryzys finansowy, korelacje, zmienność

\section{CLUSTER ANALYSIS AND SUBPRIME CRISIS}

\section{Summary}

The author uses data clustering methods derived from multivariate statistics to investigate the latest financial crisis. In compliance with these algorithms, the paper groups stock market indexes and stock exchange rates from the periods of their higher correlation and higher volatility. The author discusses the possibility to apply this method to generate time frames on the stock market. Cluster analysis has made it possible to make some new observations concerning the subprime crisis.

Key words: cluster analysis, financial crisis, correlations, volatility

\section{Wstęp}

Problemy klasyfikacji były przedmiotem zainteresowania wielu dyscyplin naukowych [Stanisz, 2007]. W tej pracy do analizy notowań okresu ostatniego kryzysu finansowego zastosowano jedną z metod grupowania z zakresu statystki wielowymiarowej - metodę analizy skupień. Dokonano tego poprzez grupowanie indeksów giełdowych oraz wybranych kursów walutowych z okresów cechujących się ich podwyższoną korelacją

\footnotetext{
${ }^{1}$ Dr Eliza Buszkowska - Wydział Prawa i Administracji, Uniwersytet Adama Mickiewicza w Poznaniu; e-mail: eliza_b2@o2.pl.
} 
i podwyższoną zmiennością. Inne charakterystyczne cechy kryzysu, które zostały opisane w literaturze przedmiotu, to duży wpływ oczekiwań na zmienność [Buszkowska, Płuciennik, 2014, s. 21-33] oraz asymetria spadków i wzrostów [Foster, Magdoff, 2009]. Ze względu na metodykę badania nie będą one brane pod uwagę. Analiza wielowymiarowa dzięki zmiennym charakteryzującym obiekty znajduje klastry obiektów podobnych. Ma zastosowanie na przykład w medycynie do: grupowania chorób, szukania metod leczenia lub symptomów chorób. W psychiatrii pozwala na poprawną diagnozę wiązek symptomów, takich jak paranoja i schizofrenia. W marketingu za jej pomocą można przeprowadzić segmentację rynku. W archeologii techniki analizy skupień wykorzystuje się ją do grupowania narzędzi kamiennych, akcesoriów pogrzebowych itd. W finansach zastosowano je między innymi w analizie portfelowej do badania spółek giełdowych [Pietrzykowski, Kobus, 2006, s. 301]. Techniki te generalnie są narzędziem do klasyfikacji zbiorów wielu zmiennych, którymi w tym badaniu sa główne europejskie indeksy giełdowe oraz ważne kursy walutowe notowane w różnych okresach. Sprawdzono, czy przy użyciu metody analizy skupień można wyróżnić okresy kryzysu, tzn. czy instrumenty finansowe z okresu kryzysu i pozostałych badanych okresów tworzyły osobne, charakterystyczne skupienia. Sprawdzono również, czy otrzymane skupienia mają jakąś prawidłowość. Zweryfikowano, czy analiza skupień wnosi nowe informacje do naszej wiedzy na temat kryzysu finansowego subprime. Należy dodać, że określenie kryzys subprime jest często stosowane $\mathrm{w}$ literaturze $\mathrm{i}$ wiąże się $\mathrm{z}$ najczęściej podawaną przyczyną ostatniego kryzysu - udzielaniem kredytów hipotecznych o podwyższonym ryzyku [Konopczak, Sieradzki, Wiernicki, 2010, s. 45-70].

W artykule oparto się na kursach walutowych względem złotego. Dobre modelowanie zmienności kursów walutowych ma istotne znaczenie, ponieważ kursy walutowe pełnią ważną funkcję w gospodarce. Kurs walutowy ma wpływ na ceny towarów na rynku i jest elementem polityki gospodarczej. Na podstawie kursów podejmuje się kluczowe decyzje, a to jeden z najważniejszych instrumentów pośredniego zarządzania handlem zagranicznym. Najistotniejszymi skutkami zmian kursów walutowych jest ich oddziaływanie na: bilans handlowy i płatniczy, inflację oraz obroty kapitału. Na rynkach finansowych zmienność kursów walutowych to element decydujący o cenach walutowych instrumentów pochodnych, które są popularnymi derywatami. W artykule uwzględniono następujące kursy walutowe:
a) EUR/PLN,
b) $\mathrm{CHF} / \mathrm{PLN}$,
c) GBP/PLN,
d) $\mathrm{USD} / \mathrm{PLN}^{2}$.

\footnotetext{
2 a) Kurs EUR/PLN. Znaczenie tego kursu dla polskiej gospodarki, a w szczególności polskiego rynku finansowego wzrosło po przystąpieniu Polski do Unii Europejskiej.

b) Kurs CHF/PLN. Frank szwajcarski był często wybieraną waluta przez osoby, które chciały zaciagnąć długoterminowy kredyt na wysoką kwotę.

c) Kurs GBP/PLN. Zmienność tego kursu stała się bardzo ważna ze względu na dużą emigrację Polaków do Wielkiej Brytanii po otwarciu rynku pracy.
} 
Były to w ostatnich latach kursy walutowe szczególnie ważne dla Polski. W pracy uwzględniono również indeksy giełdowe ważnych państw Unii Europejskiej: AEX, CAC40, DAX, FTSE100 i WIG20³ [Buszkowska, 2015], na które w znacznym stopniu mógł oddziaływać kryzys amerykański [Buszkowska, Płuciennik, 2013] oraz indeks rosyjski RTS jako indeks ważnego, częściowo europejskiego, państwa.

Badanie to pozwoli ocenić przydatność metody statystycznej, jaką jest analiza skupień, na rynku finansowym w powiązaniu z ostatnim kryzysem finansowym. Posłuży lepszemu poznaniu kryzysu subprime [Blackburn, 2008].

Autorka stawia hipotezy, że analiza skupień jest przydatną techniką do określania lat kryzysów finansowych. Ujmuje na jednym wykresie istotne informacje o okresach podwyższonej zmienności i korelacji, co byłoby trudne do zaprezentowania na klasycznych wykresach. Pozwala dostrzec, czy okres kryzysu różnił się od pozostałych ze względu na rozpatrywane zmienne. Analiza skupień jest konkurencyjnym sposobem analizowania cech kryzysów finansowych widocznych w danych giełdowych. Inaczej można tego dokonać przez klasyczne porównania indywidualne danych giełdowych. Co więcej, autorka potwierdzi nowym sposobem, że zgodnie z literatura przedmiotu, kryzys finansowy charakteryzował się wzrostem zmienności oraz wzrostem korelacji. Celem artykułu jest zweryfikowanie powyższych hipotez, a także poczynienie dodatkowych obserwacji wzbogacajacych wnioski z badania.

\section{Metodyka badania}

Przeprowadzono badanie taksonomiczne, które umożliwia grupowanie obiektów przy użyciu analizy skupień [Stanisz, 2007]. Analiza skupień jest to zbiór metod służących do wyodrębniania jednorodnych podzbiorów obiektów populacji. Jest działem statystyki wielowymiarowej. Dzięki pewnym zmiennym znajduje grupy obiektów bardziej podobnych do obiektów należących do tego samego skupienia, aniżeli do obiektów z innych skupień. Wyniki analizy skupień zależą od doboru zmiennych różnicujących

d) Kurs USD/PLN. Jak wiadomo, w dolarze są kwotowane ceny wszystkich głównych surowców (np. ropy naftowej) i stąd kurs dolara wobec złotego ma istotny wpływ na inflację w Polsce.

3 AEX (Amsterdam Exchange Index). Jest indeksem giełdowym spółek notowanych na giełdzie w Amsterdamie (Euronext Amsterdam). W jego skład wchodzi 25 największych spółek.

DAX (Deutscher Aktienindex). Jest najważniejszym indeksem Giełdy Niemieckiej (Frankfurter Wertpapierbörse, Frankfurt nad Menem). Oddaje zmianę wartości akcji 30 największych spółek akcyjnych pod względem kapitalizacji oraz obrotu.

CAC40 (Cotation Assistée en Continu). Jest francuskim indeksem akcji giełdy Euronext. Indeks ten skupia 40 najsilniejszych spółek spośród 100 o najwyższej kapitalizacji na Giełdzie Paryskiej (Bourse de Paris).

FTSE100 (skrót od Financial Times Stock Exchange). Jest indeksem akcji spółek giełdowych notowanych na Giełdzie Papierów Wartościowych w Londynie (London Stock Exchange). Indeks obejmuje 100 największych spółek spełniających liczne wymagania dotyczące: płynności, kapitalizacji itp. WIG20 (Warszawski Indeks Giełdowy) jest indeksem giełdowym 20 największych spółek akcyjnych notowanych na warszawskiej Giełdzie Papierów Wartościowych.

RTS Rosyjski indeks giełdowy to indeks 50 największych spółek notowanych na Giełdzie Papierów Wartościowych w Moskwie. 
obiekty, które można wyróżnić na podstawie literatury przedmiotu, tak by silnie różnicowały analizowane obiekty.

Istnieje wiele procedur grupowania obiektów za pomocą analizy skupień. Najczęściej stosuje się metody hierarchiczne, których rezultaty sa prezentowane w postaci specjalnych drzew, tzw. dendrogramów. Metodę hierarchiczną zastosowano w tym artykule. Innym, często wykorzystywanym, algorytmem jest metoda k-średnich, w której obiekty są przydzielane do k skupień, każdy tylko do jednego skupienia. Liczba skupień $\mathrm{k}$ jest ustalana przez badacza.

Metody hierarchiczne zawierają dwie grupy technik. Są to techniki aglomeracyjne i techniki podziałowe. $\mathrm{W}$ zastosowanych $\mathrm{w}$ tym badaniu technikach aglomeracyjnych początkowo każdy obiekt tworzy odrębne skupienie. Następnie sukcesywnie łączy się najbliższe w stosunku do siebie obiekty w nowe skupienia, aż do uzyskania jednego skupienia. Techniki podziałowe to algorytmy odwrotne. W praktyce częściej są stosowane techniki aglomeracyjne. Istnieje problem, jak określić odległość między nowymi skupieniami, innymi słowy, kiedy dwa skupienia są dostatecznie podobne, żeby je połączyć. Można wymienić wiele różnych zasad wiązania. W tym badaniu zastosowano metodę pojedynczego wiązania, zwaną również metodą najbliższego sąsiedztwa. W metodzie tej odległość między dwoma skupieniami jest wyznaczona przez odległość między dwoma najbliższymi sąsiadami należącymi do różnych skupień. Jest to metoda najbardziej intuicyjna. Inne, istniejące metody to: metoda pełnego wiązania, metoda średnich połączeń, metoda średnich połączeń ważonych, metoda środków ciężkości, metoda ważonych środków ciężkości i metoda Warda. Zostały one opisane w podręczniku do nauki programu STATISTICA [Stanisz, 2007].

Metoda pełnego wiązania (najdalszego sąsiedztwa) to metoda, w której odległość między klastrami to odległość największa. W tej pracy nie posłużono się tą metoda, ponieważ skupienia nie zawsze tworzyły zwarte kępki. Zamiast poprzedniej metody można było wykorzystać trudniejsza, lecz bardziej dokładna, a zarazem uniwersalną metodę średnich połączeń. Kolejny sposób - metodę średnich połączeń ważonych powinno się stosować, gdy skupienia są zdecydowanie różnoliczne. W tym badaniu w większości było inaczej. Metoda środków ciężkości polega na wyznaczeniu średniego punktu w przestrzeni wielowymiarowej, zdefiniowanej przez wymiary obserwacji. Byłaby odpowiednia do tego badania, gdyby nie było obserwacji odstających. Metoda ważonych środków ciężkości (mediany) wprowadza ważenie, żeby uwzględnić różne wielkości skupień. Zatem w tym badaniu nie ma zastosowania, gdyż skupienia mają w większości podobny rozmiar. Można było oszacować odległość między skupieniami, wykorzystując analizę wariancji. Metoda ta w literaturze jest opisywana jako: bardzo efektywna, chociaż zmierza do tworženia skupień o matej wielkości.

Odległość między obiektami wyznaczono za pomocą dwóch metryk: klasycznej metryki euklidesowej zdefiniowanej następująco:

$$
d(x, y)=\sqrt{\sum_{i=1}^{p}\left(x_{i}-y_{i}\right)^{2}},
$$


gdzie:

$x=\left(x_{1}, \ldots, x_{p}\right), y=\left(y_{1}, \ldots, y_{p}\right)$

oraz metryki uwzględniającej współczynnik korelacji Pearsona w postaci następującego wyrażenia:

$$
d(x, y)=1-r
$$

gdzie:

rjest współczynnikiem korelacji Pearsona [Stanisz, 2007].

Skupienia dotyczące wariancji warunkowych wyznaczono na podstawie zmienności otrzymanych jako wartości teoretyczne z parametrycznych modeli zmienności typu GARCH(1,1) w programie TSM [Doman, Doman, 2009]. Żeby wyznaczyć szeregi zmienności warunkowej z uwzględnieniem stacjonarności dla surowych danych, obliczono zwroty logarytmiczne.

\section{Dane}

W badaniu wykorzystano dzienne obserwacje notowań wybranych kursów walutowych i indeksów giełdowych wymienionych i opisanych we wstępie, pochodzące z trzech charakterystycznych okresów. Pierwszy okres to okres przed kryzysem finansowym subprime obejmujący lata: 04.01.2004 - 07.08.2007 dla indeksów giełdowych i dla kursów walutowych. Drugi przedział czasowy to okres ostatniego kryzysu finansowego. Ramy tego kryzysu zostały określone zgodnie $\mathrm{z}$ literatura przedmiotu w granicach: 08.08.2007 - 10.03.2009 [Płuciennik, 2012, s. 19-30]. Sa związane z zachowaniem spreadów LIBOR - OIS [Thornton, 2009]. Ostatni okres to okres kryzysu dłużnego od 11.03.2009 do 14.06.2013. Wybór przedziałów czasowych: 04.01.2004 - 07.08.2007 i 11.03.2009 14.06.2013 był przypadkowy. To ramy czasowe, które obejmowały wybrany, sasiedni okres przed kryzysem subprime oraz kryzys dłużny. Szeregi czasowe zostały podzielone na trzy wymienione, charakterystyczne okresy oraz na poszczególne lata. Ponieważ analiza skupień ma zastosowanie tylko do równolicznych zbiorów danych, szeregi czasowe musiały być skrócone do szeregów jednakowej długości. Należy dodać, że badanie można było zrealizować inaczej, dzieląc cała próbę nie na lata, lecz na interwały równej długości. Wtedy zapewne udałoby się wygenerować przedziały odpowiadające okresowi kryzysu. Może być to tematem innego badania.

\section{Wyniki empiryczne}

Na pierwszym etapie badania sprawdzono, czy kryzys finansowy wiązał się ze wzrostem korelacji pomiędzy indeksami giełdowymi. Wyniki w postaci dendrogramów metody hierarchicznej są zaprezentowane na rysunku pierwszym. 
RYSUNEK 1.

Dendrogram ze zmienną różnicującą, oznaczającą współczynnik korelacji Pearsona dla indeksów giełdowych

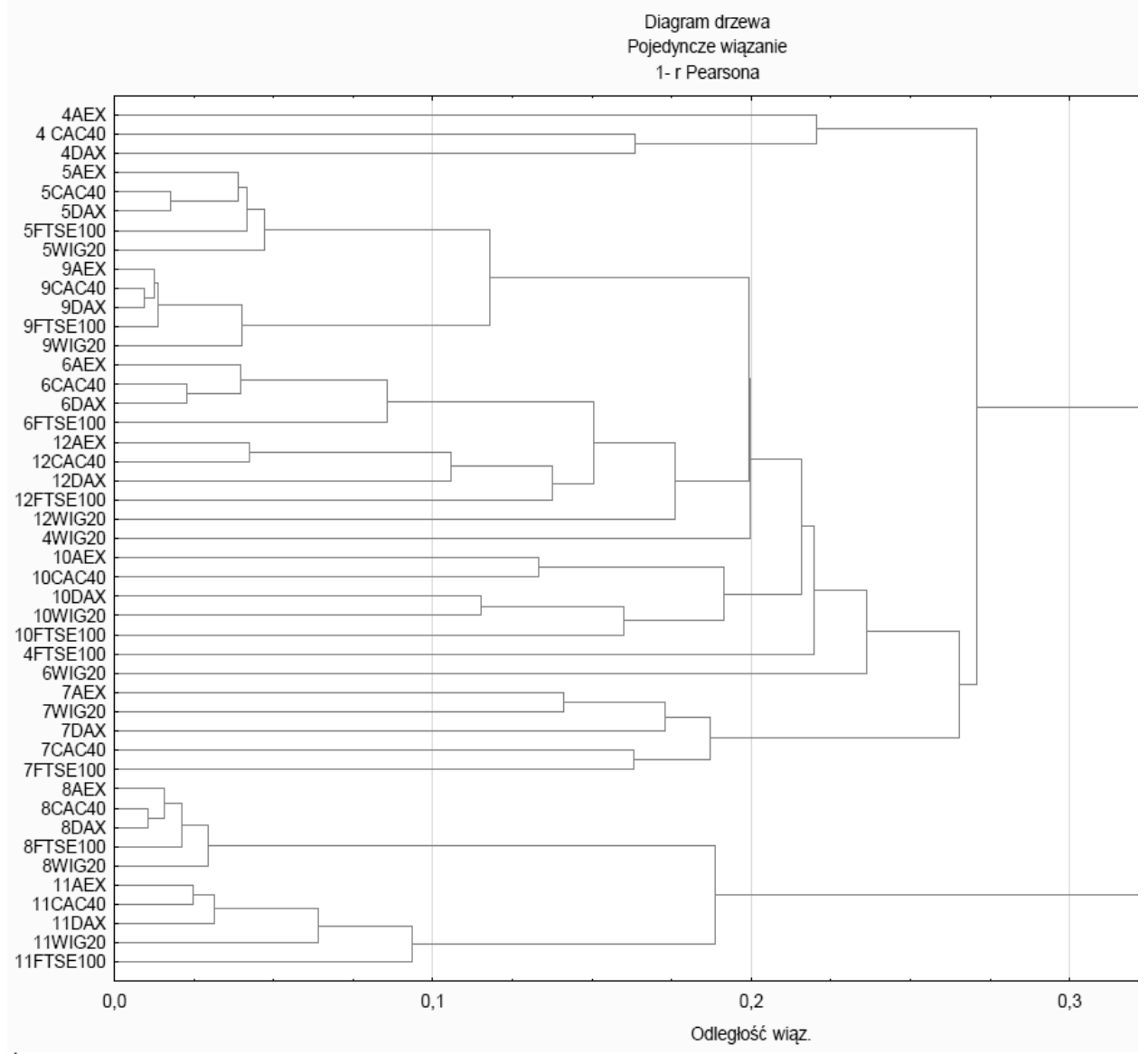

Cyfry oznaczaja poszczególne lata dwudziestego pierwszego wieku: 1 - 2001, 2 - 2002...

Źródło opracowanie własne.

Warto zauważyć, że indeksy giełdowe z okresu kryzysu finansowego, oznaczone cyframi: 7 - 2007, 8 - 2008 i 9 - 2009, nie utworzyły osobnego skupienia charakteryzującego się podwyższoną korelacją ale można wyróżnić skupienia związane z poszczególnymi latami kryzysu finansowego i pozostałymi badanymi latami, oznaczone cyframi: 4 - 2004, 5 - 2005, 6 - 2006, 10 - 2010, 11 - 2011, 12 - 2012, 13 - 2013.

Po podzieleniu danych na trzy okresy: okres przed kryzysem, okres kryzysu i okres po kryzysie uzyskano wyniki, które prezentuje rysunek 2. 
Dendrogram prezentuje zmienną różnicująca, oznaczającą współczynnik korelacji Pearsona dla indeksów giełdowych. Cyfry określają trzy wyszczególnione okresy: 1 przed, 2 - w trakcie i 3 - po ostatnim kryzysie finansowym.

RYSUNEK 2.

Dendrogram ze zmienną różnicującą, oznaczającą współczynnik korelacji Pearsona dla indeksów giełdowych

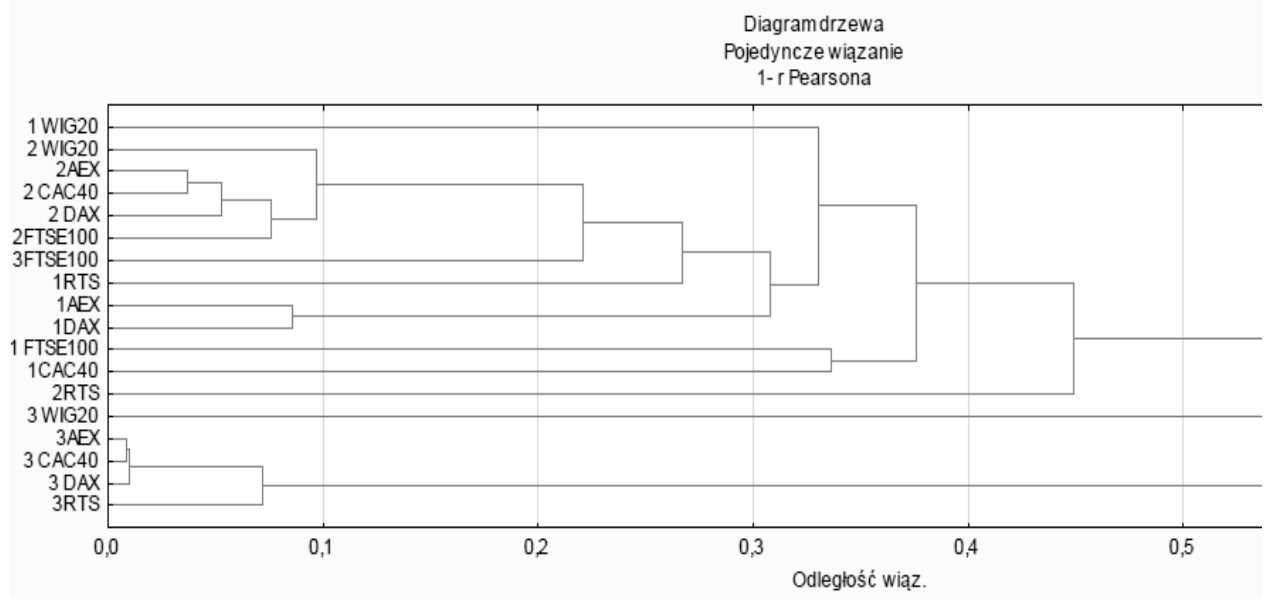

Źródło opracowanie własne.

Można zauważyć, że notowania z okresu kryzysu były bardziej skorelowane niż notowania z pozostałych okresów. Utworzyły one charakterystyczne skupienie oznaczone na wykresie cyfrą 2. Wyjątek stanowił RTS, który jest indeksem państwa spoza Unii Europejskiej. Wśród wskaźników rynków Unii Europejskiej powiązania były znaczne. W przypadku okresu trzeciego wyjątek utworzyły aż dwa indeksy: indeks brytyjski $\mathrm{i}$ indeks WIG20, które nie były silnie skorelowane z pozostałymi.

Następnie przeprowadzono analizę zmienności. Wyniki prezentuje rysunek 3. 
RYSUNEK 3.

\section{Dendrogram ze zmienną różnicującą wariancję warunkową dla indeksów giełdowych}

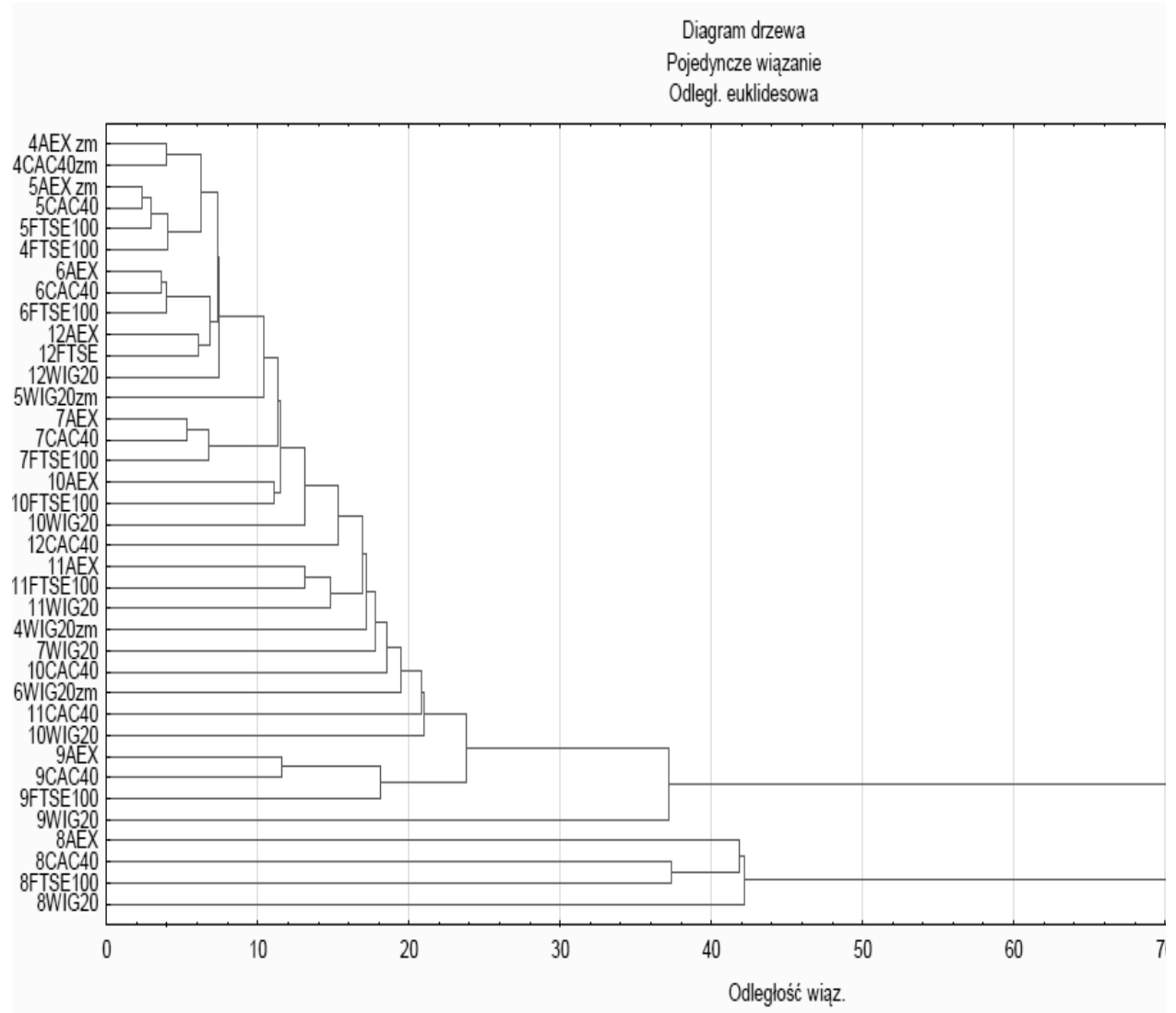

Cyfry oznaczaja poszczególne lata dwudziestego pierwszego wieku.

Źródło opracowanie własne.

Stwierdzono, że w latach 2008 i 2009 zmienności były wyraźnie odmienne. Indeksy giełdowe z tymi zmiennościami utworzyły osobne skupienie. Zmienności w pozostałych okresach kształtowały się nieregularnie.

Po wyróżnieniu trzech charakterystycznych okresów przed kryzysem, w czasie kryzysu i po kryzysie można zauważyć, że obiekty z okresu kryzysu finansowego zostały sklasyfikowane do tej samej grupy. Cechuje się ona dużym zróżnicowaniem elementów. Obiekty z pozostałych dwóch okresów są rozrzucone na osi. 
RYSUNEK 4.

Dendrogram ze zmienną różnicującą wariancję warunkową dla indeksów giełdowych

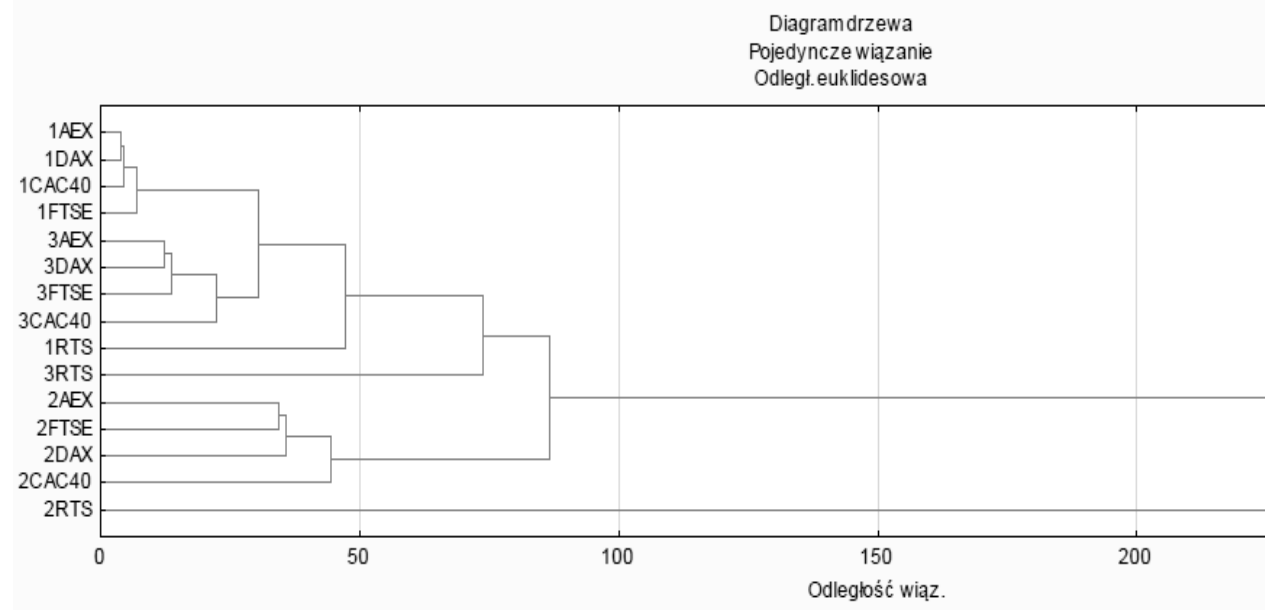

Źródło opracowanie własne.

Drugie badanie przeprowadzono dla kursów walutowych względem złotego. Najpierw dokonano analizy korelacji.

RYSUNEK 5.

Diagram drzewa przedstawiający skupienia dla trzech wyróżnionych okresów kursów walutowych

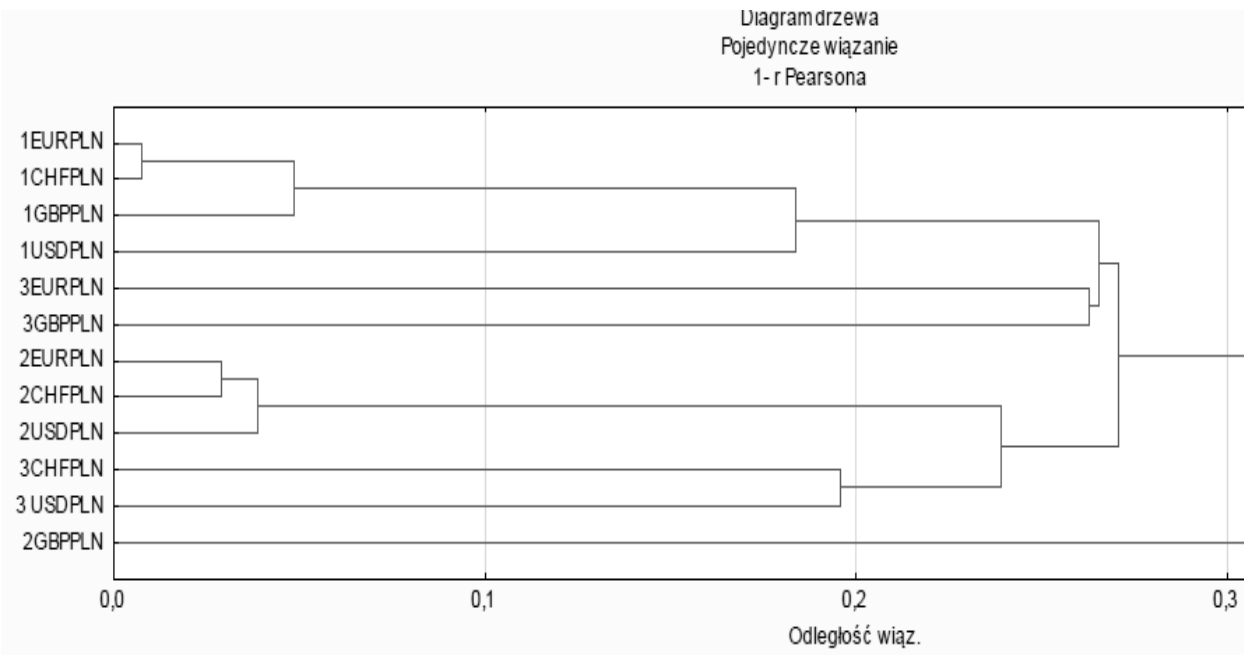

Źródło opracowanie własne. 
Warto zauważyć, że również dla kursów walutowych istniały wysokie korelacje w okresie kryzysu. Kursy walutowe z okresu kryzysu (2) utworzyły skupienie charakteryzujące się wysokimi korelacjami. W pozostałych okresach korelacje pomiędzy kursami walutowymi były małe, $z$ wyjątkiem pary EUR/PLN-CHF/PLN.

RYSUNEK 6.

Diagram drzewa przedstawiający skupienia różnych lat dwudziestego pierwszego wieku dla kursów walutowych

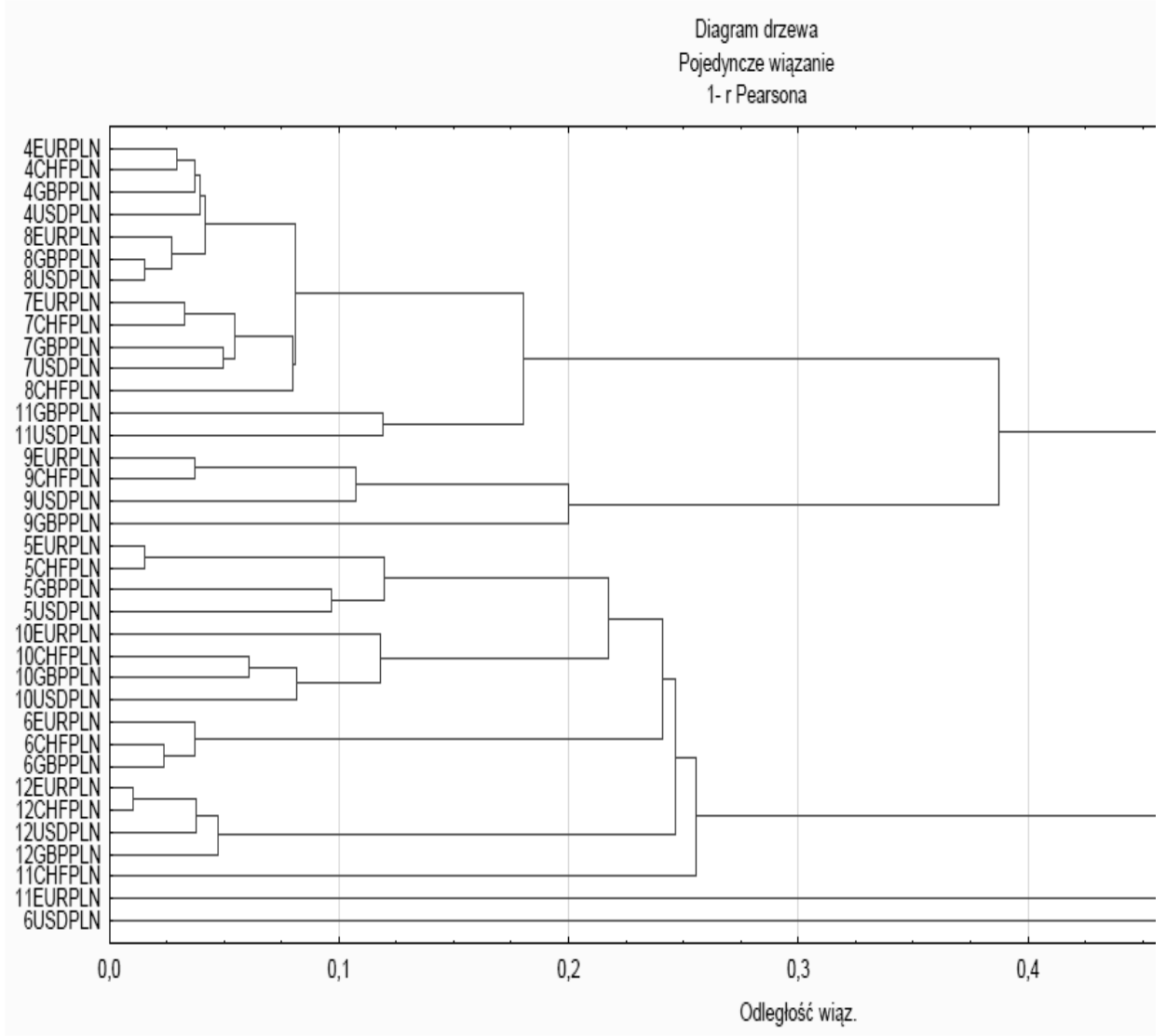

Źródło opracowanie własne.

Można zaobserwować, że przy podziale obiektów na lata nie można wygenerować ram kryzysu za pomocą analizy skupień, jeżeli za zmienną różnicującą obiekty przyjmie się współczynnik korelacji Pearsona. Podobnie jak dla indeksów giełdowych, skupienia były związane z poszczególnymi latami (kursy walutowe z tych okresów są zgrupowane blisko siebie). 
RYSUNEK 7.

Diagram drzewa przedstawiający skupienia różnych lat dwudziestego pierwszego wieku dla kursów walutowych, wyznaczone ze względu na zmienność

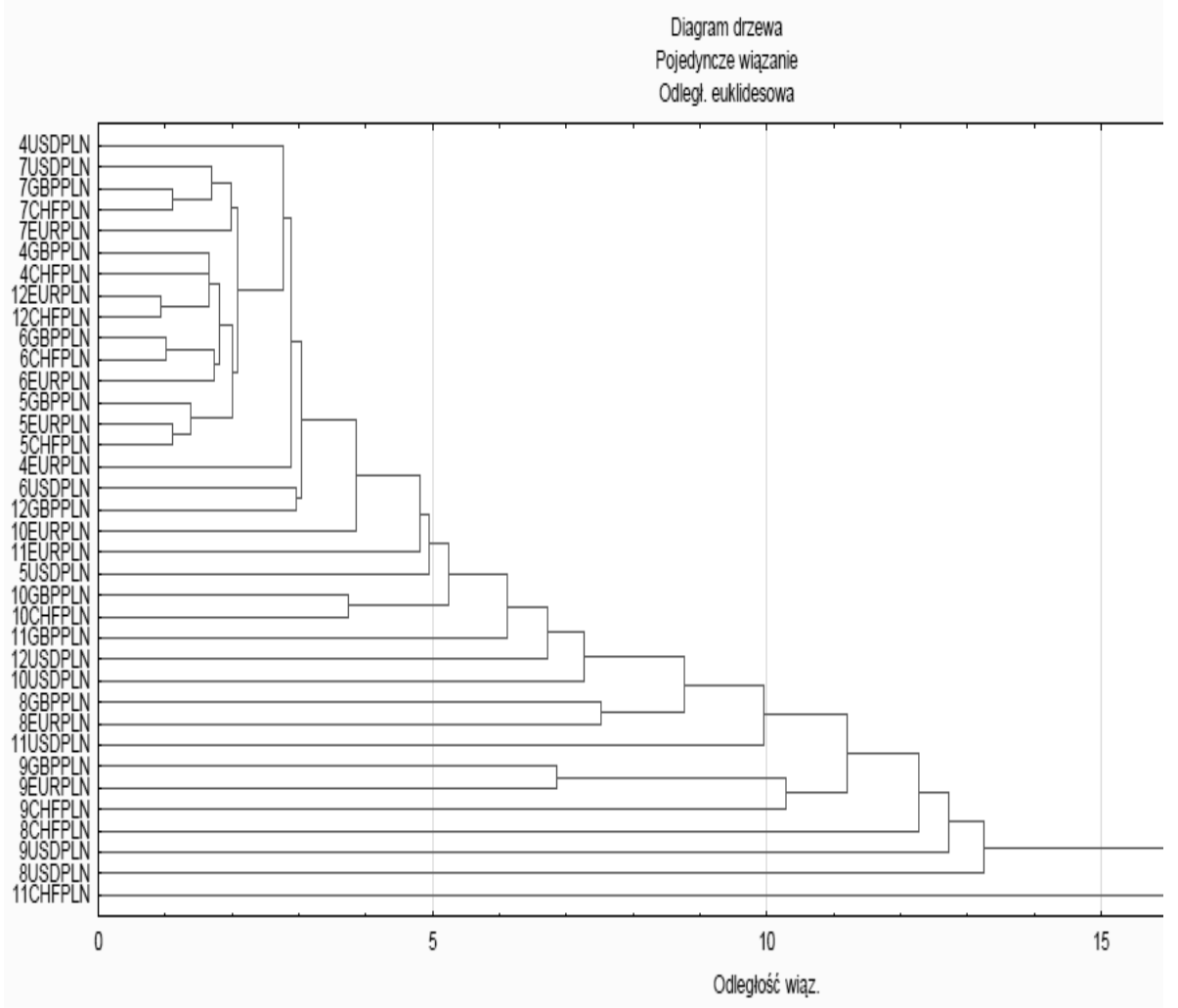

Źródło opracowanie własne.

Stwierdzono, że w latach 2008 i 2009 zmienności utworzyły osobne skupienie. Zmienności w pozostałych okresach kształtowały się nieregularnie. Rok 2007 nie został ujęty prawdopodobnie z uwagi na to, że początek kryzysu subprime to dopiero 08.08.2007 roku, a do analizy pobierano dane również z początku roku 2007. 
RYSUNEK 8. Diagram drzewa przedstawiający skupienia dla trzech wyróżnionych okresów dla kursów walutowych, wyznaczone ze względu na zmienność

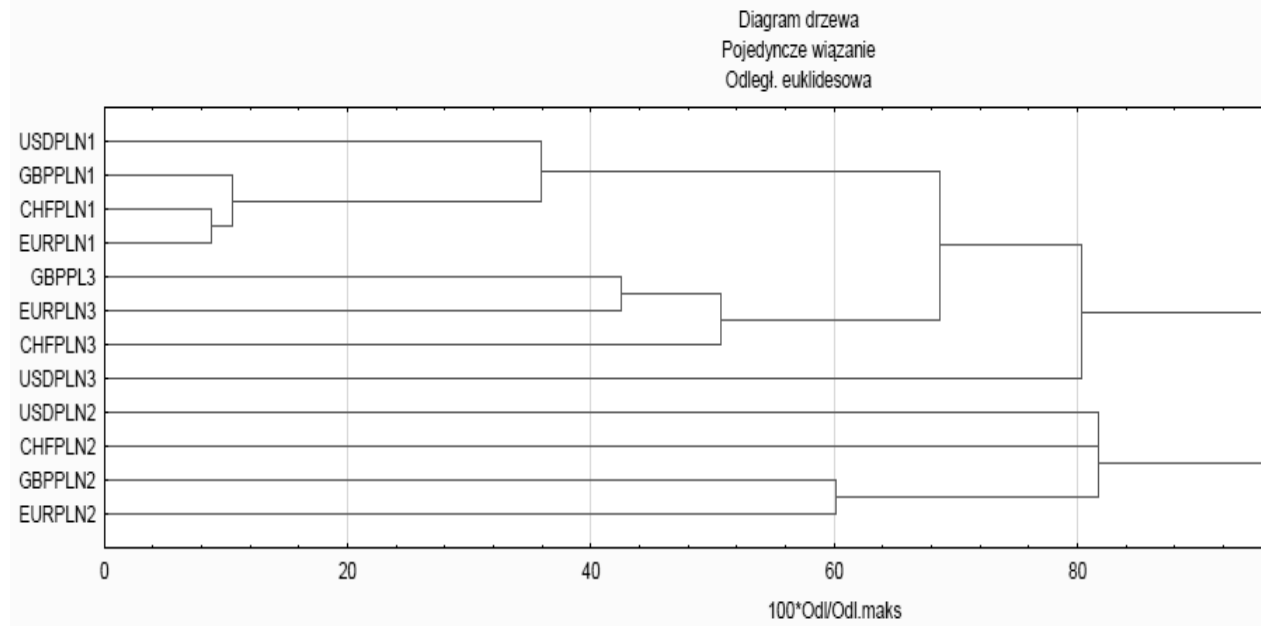

Źródło opracowanie własne.

Na ostatnim etapie badania wyróżniono trzy charakterystyczne okresy: 1 - przed kryzysem, 2 - w czasie kryzysu i 3 - po kryzysie. Warto zauważyć, że obiekty z okresu kryzysu finansowego zostały sklasyfikowane do tej samej grupy (cechującej się większą zmiennościa).

W analizie heteroskedastyczności warunkowej indeksów giełdowych wykorzystano poniższe modele $z$ rodziny GARCH.

Do zwrotów logarytmicznych z indeksu WIG20 dopasowano model FIGARCH(1,1).

\section{Estymacje parametrów modelu}

\begin{tabular}{|c|c|c|c|c|}
\hline WIG20 & $\begin{array}{c}\text { Estymacja para- } \\
\text { metru }\end{array}$ & $\begin{array}{l}\text { Błąd standar- } \\
\text { dowy }\end{array}$ & $\begin{array}{c}\text { Statystyka } \\
t\end{array}$ & p-wartość \\
\hline [2]GARCH Intercept & 0,02175 & 0,0109 & $\begin{array}{ll}----- \\
\end{array}$ & ----- \\
\hline FIGARCH d & 0,67489 & 0,0825 & ----- & ------ \\
\hline GARCH Alpha1 & $-0,66902$ & 0,08256 & $-8,103$ & 0 \\
\hline GARCH Beta1 & 0,78735 & 0,05032 & 15,647 & 0 \\
\hline & Statystyka testowa & p-wartość & & \\
\hline Box-Pierce (reszty) & $\mathrm{Q}(12)=12,9809$ & 0,37 & & \\
\hline $\begin{array}{l}\text { Box-Pierce } \\
\text { (kwadraty reszt) }\end{array}$ & $\mathrm{Q}(12)=11,9601$ & 0,449 & & \\
\hline
\end{tabular}

Źródło opracowanie własne.

TABELA 1. 
Dla zwrotów logarytmicznych z indeksu FTSE100 otrzymano model GARCH(1,1). Jest to najbardziej podstawowy model parametryczny heteroskedastyczności warunkowej. Jego dopasowanie świadczy np. o braku długiej pamięci w danych, braku efektu dźwigni bądź innych cechach szeregu czasowego, które uwzględniają inne, sprawdzane przez autorkę modele.

\section{Estymacje parametrów modelu}

\begin{tabular}{|c|c|c|c|c|}
\hline FTSE100 & $\begin{array}{l}\text { Estymacja } \\
\text { parametru }\end{array}$ & Błąd standardowy & Statystyka t & p-wartość \\
\hline [2]GARCH Intercept & 0,01701 & 0,0049 & $\begin{array}{ll}----- \\
-1\end{array}$ & $-\cdots---$ \\
\hline GARCH Alpha1 & 0,10032 & 0,01723 & 5,822 & 0 \\
\hline \multirow[t]{2}{*}{ GARCH Beta1 } & 0,88781 & 0,01805 & 49,186 & 0 \\
\hline & $\begin{array}{c}\text { Statystyka } \\
\text { testowa }\end{array}$ & p-wartość & & \\
\hline Box-Pierce (reszty) & $\mathrm{Q}(12)=7,3193$ & 0,836 & & \\
\hline $\begin{array}{l}\text { Box-Pierce } \\
\text { (kwadraty reszt): }\end{array}$ & $\mathrm{Q}(12)=18,063$ & 0,114 & & \\
\hline
\end{tabular}

Źródło opracowanie własne.

Dla zwrotów logarytmicznych z indeksu CAC40 osiąnięto model ARIMA(1,0,1) FIGARCH(1,1). Jest to model zmienności warunkowej z długą pamięcią. Dobór ARIMA wartości oczekiwanej oznacza, że dane zlogarytmowane były niestacjonarne.

\section{Estymacje parametrów modelu}

\begin{tabular}{|c|c|c|c|c|}
\hline CAC40 & $\begin{array}{l}\text { Estymacja pa- } \\
\text { rametru }\end{array}$ & Błąd standardowy & Statystyka t & p-wartość \\
\hline Student's t d.f. & 8,80242 & 1,6217 & \begin{tabular}{l|l}
----- \\
-1
\end{tabular} & $\begin{array}{c}----- \\
-\end{array}$ \\
\hline Skośność (ksi) & 0,85578 & 0,026 & ----- & ----- \\
\hline AR1 & 0,70429 & 0,07511 & 9,377 & 0 \\
\hline MA1 & 0,77708 & 0,06622 & 11,735 & 0 \\
\hline GARCH Intercept & 0,17017 & 0,0322 & \begin{tabular}{l|l}
----- \\
\end{tabular} & ----- \\
\hline \begin{tabular}{|l|} 
FIGARCH d \\
\end{tabular} & 0,49212 & 0,1137 & - ----- & $\begin{array}{c}----- \\
\end{array}$ \\
\hline GARCH AR1 & $-0,00293$ & 0,06816 & $-0,043$ & 0,966 \\
\hline \multirow[t]{2}{*}{ GARCH MA1 } & 0,48536 & 0,14458 & 3,357 & 0,001 \\
\hline & Statystyka testowa & p-wartość & & \\
\hline Box-Pierce (reszty) & $\mathrm{Q}(10)=12,1124$ & 0,278 & & \\
\hline $\begin{array}{l}\text { Box-Pierce } \\
\text { (kwadraty reszt) }\end{array}$ & $Q(12)=16,3314$ & 0,177 & & \\
\hline
\end{tabular}

Źródło opracowanie własne.

Dla zmiennej zależnej DAX - zwrot logarytmiczny uzyskano model GARCH(1,1). Ograniczenie do dwóch parametrów w tym modelu nie dowodzi tego, że model ten wypada gorzej niż inne modele. Jest to prawidłowość znana z literatury. 
Estymacje parametrów modelu

\begin{tabular}{|c|c|c|c|c|}
\hline DAX & $\begin{array}{c}\text { Estymacja parame- } \\
\text { tru }\end{array}$ & $\begin{array}{l}\text { Błąd standar- } \\
\text { dowy }\end{array}$ & $\begin{array}{c}\text { Statystyka } \\
t\end{array}$ & p-wartość \\
\hline [2]GARCH Intercept & 0,02597 & 0,0079 & 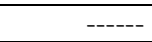 & $\begin{array}{ll}----- \\
-1\end{array}$ \\
\hline GARCH Alpha1 & 0,08444 & 0,01418 & 5,955 & 0 \\
\hline GARCH Beta1 & 0,90145 & 0,01482 & 60,827 & 0 \\
\hline & Statystyka testowa & p-wartość & & \\
\hline Box-Pierce (reszty) & $\mathrm{Q}(12)=5,639$ & 0,933 & & \\
\hline $\begin{array}{l}\text { Box-Pierce } \\
\text { (kwadraty reszt): }\end{array}$ & $\mathrm{Q}(12)=17,7288$ & 0,124 & & \\
\hline
\end{tabular}

Źródło opracowanie własne.

Dla zmiennej zależnej AEX - zwrot logarytmiczny otrzymano model GARCH(1,1).

TABELA 5.

\section{Estymacje parametrów modelu}

\begin{tabular}{|c|c|c|c|c|}
\hline AEX & $\begin{array}{l}\text { Estymacja } \\
\text { parametru }\end{array}$ & $\begin{array}{l}\text { Błąd standar- } \\
\text { dowy }\end{array}$ & Statystyka $t$ & p-wartość \\
\hline [2]GARCH Intercept & 0,02301 & 0,0069 & ------ & ------ \\
\hline GARCH Alpha1 & 0,10259 & 0,01719 & 5,968 & 0 \\
\hline GARCH Beta1 & 0,88382 & 0,01805 & 48,965 & 0 \\
\hline & Statystyka testowa & p-wartość & & \\
\hline Box-Pierce (reszty) & $\mathrm{Q}(12)=11,3361$ & 0,5 & & \\
\hline $\begin{array}{c}\text { Box-Pierce } \\
\text { (kwadraty reszt) }\end{array}$ & $\mathrm{Q}(12)=8,3526$ & 0,757 & & \\
\hline
\end{tabular}

Źródło opracowanie własne.

Modele klasy GARCH zostały wybrane do badania ze względu na ich dużą popularność.

Sprawdzono za pomocą dendrogramu, czy można dla kursów walutowych względem złotego określić lata kryzysu na podstawie zmienności, co zostało przedstawione wcześniej. Wariancje warunkowe zostały wyznaczone za pomocą modeli GARCH(1,1). Dla zwrotów logarytmicznych z kursu walutowego CHF/PLN uzyskano model GARCH(1,1). 
Estymacje parametrów modelu

\begin{tabular}{|l|r|r|r|r|}
\hline \multicolumn{1}{|c|}{ CHF/PLN } & $\begin{array}{c}\text { Estymacja para- } \\
\text { metru }\end{array}$ & $\begin{array}{c}\text { Błąd standardo- } \\
\text { wy }\end{array}$ & Statystyka t & p-wartość \\
\hline $\begin{array}{l}{[2] \text { GARCH In- }} \\
\text { tercept }\end{array}$ & 0,00672 & 0,0025 & ----- & ------- \\
\hline GARCH Alpha1 & 0,07301 & 0,01229 & 5,941 & 0 \\
\hline GARCH Beta1 & 0,91689 & 0,01363 & 67,27 & \\
\hline & Statystyka testowa & p-wartość & & \\
\cline { 1 - 3 } $\begin{array}{l}\text { Box-Pierce } \\
\text { (reszty) }\end{array}$ & $\mathrm{Q}(12)=11,3754$ & 0,497 & & \\
\cline { 1 - 3 } $\begin{array}{l}\text { Box-Pierce } \\
\text { (kwadraty reszt) }\end{array}$ & $\mathrm{Q}(12)=16,9549$ & 0,151 & & \\
\hline
\end{tabular}

Źródło opracowanie własne.

Dla zwrotów logarytmicznych z kursu walutowego GBP/PLN otrzymano model $\operatorname{GARCH}(1,1)$.

TABELA 7.

\section{Estymacje parametrów modelu}

\begin{tabular}{|c|c|c|c|}
\hline GBP/PLN & $\begin{array}{l}\text { Estymacja para- } \\
\text { metru }\end{array}$ & $\begin{array}{l}\text { Błąd standar- } \\
\text { dowy }\end{array}$ & p-wartość \\
\hline $\begin{array}{l}\text { [2]GARCH In- } \\
\text { tercept }\end{array}$ & 0,01121 & 0,0035 & ------ \\
\hline GARCH Alpha1 & 0,07182 & 0,01182 & 0 \\
\hline GARCH Beta1 & 0,90952 & 0,01594 & 0 \\
\hline & Statystyka testowa & p-wartość & \\
\hline Box-Pierce (reszty) & $\mathrm{Q}(12)=14,1131$ & 0,294 & \\
\hline $\begin{array}{l}\text { Box-Pierce } \\
\text { (kwadraty reszt): }\end{array}$ & $\mathrm{Q}(12)=11,5862$ & 0,479 & \\
\hline
\end{tabular}

Źródło opracowanie własne.

Dla zwrotów logarytmicznych z kursu walutowego EUR/PLN uzyskano model $\operatorname{GARCH}(1,1)$.

TABELA 8.

Estymacje parametrów modelu

\begin{tabular}{|c|c|c|c|}
\hline EUR/PLN & $\begin{array}{c}\text { Estymacja para- } \\
\text { metru }\end{array}$ & $\begin{array}{l}\text { Błąd standar- } \\
\text { dowy }\end{array}$ & p-wartość \\
\hline $\begin{array}{l}\text { [2]GARCH In- } \\
\text { tercept }\end{array}$ & 0,00471 & 0,0018 & ------ \\
\hline GARCH Alpha1 & 0,07297 & 0,01256 & 0 \\
\hline GARCH Beta1 & 0,9148 & 0,01525 & 0 \\
\hline & Statystyka testowa & p-wartość & \\
\hline Box-Pierce (reszty) & $\mathrm{Q}(12)=8,9317$ & 0,709 & \\
\hline $\begin{array}{l}\text { Box-Pierce } \\
\text { (kwadraty reszt) }\end{array}$ & $Q(12)=11,4383$ & 0,492 & \\
\hline
\end{tabular}

Źródło opracowanie własne. 
Dla zwrotów logarytmicznych z kursu walutowego USD/PLN otrzymano model $\operatorname{GARCH}(1,1)$.

\section{Estymacje parametrów modelu}

TABELA 9.

\begin{tabular}{|c|c|c|c|c|}
\hline USD/PLN & $\begin{array}{c}\text { Estymacja para- } \\
\text { metru }\end{array}$ & $\begin{array}{l}\text { Błąd standar- } \\
\text { dowy }\end{array}$ & $\begin{array}{c}\text { Statystyka } \\
t\end{array}$ & p-wartość \\
\hline $\begin{array}{l}\text { [2]GARCH In- } \\
\text { tercept }\end{array}$ & 0,0143 & 0,0048 & $\begin{array}{ll}----- \\
\end{array}$ & $\begin{array}{c}---- \\
-1\end{array}$ \\
\hline GARCH Alpha1 & 0,07471 & 0,01089 & 6,86 & 0 \\
\hline GARCH Beta1 & 0,91117 & 0,01369 & 66,558 & 0 \\
\hline & Statystyka testowa & p-wartość & & \\
\hline Box-Pierce (reszty) & $Q(12)=11,3655$ & 0,498 & & \\
\hline $\begin{array}{l}\text { Box-Pierce } \\
\text { (kwadraty reszt) }\end{array}$ & $\mathrm{Q}(12)=7,9678$ & 0,788 & & \\
\hline
\end{tabular}

Źródło opracowanie własne.

Wszystkie modele heteroskedastyczności warunkowej zostały zweryfikowane pozytywnie. Wynika to stad, że miały one istotne parametry statystyczne i spełniały warunek stacjonarności, tzn. suma parametrów modelu GARCH $(1,1)$ była mniejsza od jednego. Ponadto nie było zasadniczych korelacji w resztach standaryzowanych i kwadratach reszt standaryzowanych, co stwierdzono na podstawie testu Boxa-Pierce, [Doman, Doman, 2009]. Zatem było można na podstawie tych modeli poprawnie wnioskować o zmienności badanych danych.

\section{Podsumowanie}

Analizę skupień można wykorzystać do potwierdzenia, że dane pochodzą z kryzysu. Jest to wygodna metoda, jeśli chcemy na jednym wykresie w sposób sumaryczny ująć informacje o dłuższym interwale czasowym. Indeksy giełdowe i kursy walutowe reprezentujące poszczególne lata kryzysu finansowego nie utworzyły osobnego skupienia z podwyższoną korelacją ale można wyróżnić skupienia związane z różnymi latami kryzysu finansowego i kastry obserwacji z poszczególnych, innych lat. Po wyodrębnieniu obiektów ukazujących okres kryzysu finansowego zauważono, że odpowiadające im notowania kursów walutowych i ważnych indeksów giełdowych Unii Europejskiej były bardziej skorelowane niż notowania z pozostałych okresów i utworzyły charakterystyczne skupienie. Zarówno dla kursów walutowych, jak i dla indeksów giełdowych stwierdzono, że w latach 2008 i 2009 ich zmienności były szczególne. Jednak nie można na podstawie wyników analizy wielowymiarowej wnioskować, że były one wyższe. Zmienności w pozostałych okresach kształtowały się nieregularnie i odpowiadające im obiekty nie zostały zgrupowane razem. Po wyróżnieniu trzech okresów: przed kryzysem, w trakcie kryzysu i po kryzysie finansowym można zaobserwować, że obiekty reprezentujące okres kryzysu miały charakterystyczną (wyższa) zmienność. Ponadto indeksy giełdowe i kursy walutowe w okresie kryzysu bardziej różniły się od siebie zmiennoś- 
cią niż w okresach spokoju. Należy podkreślić, że analiza skupień może być wykorzystywana do weryfikowania własności charakterystycznych okresów na giełdzie, nie zaś do określania ich ram czasowych, gdy za jednostkę podziału przyjmie się kolejne lata. Dzięki nowej metodzie w okresie kryzysu potwierdzono wyższe korelacje zarówno dla indeksów giełdowych, jak i kursów walutowych. Co więcej, podobne korelacje były związane z obiektami pochodzącymi z tych samych lat. Należy wspomnieć, że wykryte korelacje świadczyły o współwystępowaniu obserwacji (podobnych tendencjach na wykresie), a nie o zależnościach przyczynowo-skutkowych, gdyż w przypadku korelacji nie operowano szeregami stacjonarnymi. Jednak dla inwestora, który dokonuje inwestycji na giełdzie, bardziej interesująca może być sama relacja wykresów notowań, a nie wzajemne wpływy jednych instrumentów finansowych na drugie. Stąd autorka w tym artykule zrezygnowała $z$ analizy stacjonarności. Badania dla szeregów stacjonarnych w postaci stóp zwrotu zostały już opisane w artykułach z odnośnikami [Doman, Doman, 2014; Buszkowska, 2010; Buszkowska, 2015]. Warto dodać, że dla szeregów stacjonarnych, uzyskanych poprzez wyliczenie stóp zwrotu, w kryzysie subprime nie było w większości istotnych korelacji pomiędzy indeksami, a także pomiędzy kursami walutowymi. Zatem analiza skupień dla danych stacjonarnych potwierdziłaby tylko wyniki przedstawione w literaturze. Najważniejsza hipoteza o możliwości zastosowania analizy skupień do generowania ram czasowych charakterystycznych okresów na giełdzie przy podziale próby na lata i skracaniu szeregów została odrzucona. Być może byłoby inaczej, gdyby podziału na okresy dokonano w inny sposób, bez skracania próby. Pozytywnie udało się zweryfikować pozostałe hipotezy i na podstawie przeprowadzonego badania sformułować dodatkowe wnioski, dlatego też cel artykułu został osiagnięty.

\section{Literatura}

Blackburn R. 2008 The Subprime Crisis, New Left Review, 50, March, April.

Buszkowska E. 2010 Badanie zależności między indeksami giełdowymi a kursami walutowymi, Zeszyty Naukowe Uniwersytetu Ekonomicznego w Krakowie, Kraków.

Buszkowska E. 2015 Dynamika preptywów inwestycji pomiędzy giełdami, AUNC Ekonomia, Toruń.

Buszkowska E., Płuciennik P. 2013 Wplyw kryzysu subprime na polski rynek kapitałowy, „Ekonomiczne i etyczne aspekty kryzysu gospodarczego”, nr 1.

Buszkowska E., Płuciennik P. 2014 Wptyw krysysu subprime na determinanty wariancii warunkowej indeksu WIG20, „Matematyka i informatyka na usługach ekonomii”, Wydawnictwo Uniwersytetu Ekonomicznego w Poznaniu, Poznań.

Doman M., Doman R. 2009 Modelowanie żmienności i ryzyka. Metody ekonometrii finansowej, Oficyna a Wolter Kluwer Business, Kraków.

Doman M., Doman R. 2014 Dynamika zależności na globalnym rynku finansowym, Wydawnictwo Difin, Warszawa.

Foster J.B., Magdoff F. 2009 The great financial crisis, causes and consequences, Monthly Review Press, New York. 
Konopczak M., Sieradzki R., Wiernicki M. 2010 Kryzys na światonyych rynkach finansowych - wplyw na rynek. finansouy w Polsce oraz implikacje dla sektora realnego, „Bank i Kredyt", nr 41 (6).

Migut G. 2009 Zastosowanie technik analisy skupień i dræew decysyjnych do segmentacji rynku, dokument elektroniczny, tryb dostępu: [http://www.statsoft.pl/portals/0/ Downloads/Zastosowanie_technik.pdf, data wejścia: 11.05.2009].

Pietrzykowski R., Kobus P. Zastosowanie modyfikacii metody k-średnich w analizie portfelowej, dokument elektroniczny, tryb dostępu: [http://www.wne.sggw.pl/czasopisma/ pdf/EIOGZ_2006_nr60_s301.pdf, data wejścia: 11.05.2009].

Płuciennik P. 2012 Influence of the American Financial Market on Other Markets During the Subprime Crisis, Folia Oeconomica Stetinensia, Szczecin.

Stanisz A. 2007 Proystepny kurs statystyki z zastosowaniem STATISTICA PL na prayketadach z medycyny. Tom 3. Analizy wielowymiarowe, Statsoft, Kraków.

Thornton D. L. 2009 What the Libor-OIS Spread Says, „Economic Synopses”, 24, Federal Reserve Bank of St. Louis, dokument elektroniczny, tryb dostępu: [https://research.stlouisfed.org/publications/es/09/ES0924.pdf, data wejścia: 11.05.2009]. 